\title{
Instrumen Evaluasi Non-Tes dalam Penilaian Hasil Belajar Ranah Afektif dan Psikomotorik
}

\author{
Rinto Hasiholan Hutapea \\ Sekolah Tinggi Agama Kristen Negeri Kupang, Nusa Tenggara Timur \\ rintohutapea81@gmail.com
}

\begin{abstract}
Abstact: The Non-test Evaluation Instrument That Is Ignored in the Assessment of Affective and Psychomotor domains. This study aims to see the description of Christian Religious Education teachers in using non-test evaluation instruments in evaluating the learning outcomes of the affective and psychomotor domains of students. The method used in this research is survey method and literature study. Where it is explained that to measure and assess the learning outcomes of the affective and psychomotor domains, the right type of instrument to use is the non-test. The findings of this study explain that Christian Education teachers in SMP Negeri 5 and SMP Negeri 20 Kota Kupang are still low in using non-test evaluation instruments. The indicator is that teachers have difficulty using non-test evaluation instruments, and do not have time to prepare non-test evaluation instruments in evaluating the affective and psychomotor domains of students.
\end{abstract}

Keywords: affective; Christian religious education; learning outcomes; non-test evaluation; psychomotor

\begin{abstract}
Abstrak: Instrumen Evaluasi Non-tes yang Terabaikan Dalam Penilaian Ranah Afektif dan Psikomotorik. Penelitian ini memiliki tujuan untuk melihat gambaran guru-guru Pendidikan Agama Kristen dalam menggunakan instrumen evaluasi nontes dalam penilaian hasil belajar ranah afektif dan psikomotorik peserta didik.Metode yang digunakan dalam penelitian ini adalah metode survei dan studi pustaka.Dimana dijelaskan bahwa untuk mengukur dan menilai hasil belajar ranah afektif dan psikomotorik, jenis instrumen yang tepat digunakan adalah non-tes. Temuan hasil penelitian ini menerangkan bahwa guru-guru Pendidikan Agama Kristen di SMP Negeri 5 dan SMP Negeri 20 Kota Kupang masih rendah dalam menggunakan instrumen evaluasi non-tes. Indikatornya adalah guru-guru mengalami kesulitan menggunakan instrumen evaluasi non-tes, serta tidak memiliki waktu untuk mempersiapkan instrumen evaluasi non-tes dalam penilaian ranah afektif dan psikomotorik peserta didik.
\end{abstract}

Kata kunci: afektif; evaluasi non-tes; hasil belajar; pendidikan agama Kristen; psikomotorik

\begin{tabular}{llll}
\hline Article History : & Received: 11-04-2019 & Revised: 18-07-2019 Accepted: 30-12-2019
\end{tabular}

\section{Pendahuluan}

Peraturan Pemerintah No 19, tahun 2005 tentang Standar Nasional Pendidikan, khususnya Bab II Pasal 2 ayat (1) menjelaskan bahwa terdapat delapan Standar Nasional Pendidikan. Salah satunya adalah standar kompetensi lulusan.Standar kompetensi 
lulusan adalah kualifikasi kemampuan lulusan yang mencakup sikap, pengetahuan, dan keterampilan. ${ }^{1}$ Peraturan pemerintah tersebut secara khusus yang berkaitan dengan kompetensi lulusan, menunjukkan bahwa kualifikasi sikap, pengetahuan, dan keterampilan menjadi ranah yang sangat penting untuk mendapat perhatian.Menurut teori Benjamin S. Bloom dalam Asep dan Abdul Haris, ketiga ranah ini disebut sebagai hasil belajar yang meliputi ranah kognitif, afektif dan psikomotorik. ${ }^{2}$ Ranah kognitif berkaitan dengan pengetahuan, ranah afektif berkaitan dengan sikap, dan ranah psikomotorik berkaitan dengan keterampilan.

Asep dan Haris lebih lanjut menjelaskan pengertian dari hasil belajar. Mereka menguraikan hasil belajar ialah segala sesuatu yang menjadi milik peserta didik sebagai akibat dari kegiatan belajar yang dilakukannya. Tujuan belajar pada bagian ini merupakan sejumlah hasil belajar yang menunjukkan bahwa peserta didik telah melakukan perbuatan belajar, yang umumnya meliputi pengetahuan, keterampilan dan sikap-sikap yang baru, yang diharapkan dapat dicapai oleh peserta didik. ${ }^{3}$

Ketiga jenis ranah hasil belajar yang disebutkan di atas, masing-masing ranah memiliki alat ukur atau instrumen yang pasti dan terukur. Untuk mengukur hasil belajar ranah kognitif (pengetahuan teoretis) dapat menggunakan teknik tes. Sedangkan untuk mengukur hasil belajar ranah afektif dan psikomotorik dapat menggunakan teknik non-tes. Seperti yang diungkapkan oleh Nana Sudjana yang menegaskan perihal hasil belajar dan proses belajar tidak hanya dapat dinilai dengan menggunakan teknik tes berupa bentuk tes uraian maupun tes objektif, melainkan juga dapat dinilai dengan menggunakan teknik non-tes. ${ }^{4}$ Teknik tes maupun non-tes merupakan bagian yang tidak terpisahkan dalam mengukur hasil belajar ranah kognitif, afektif, maupun psikomotorik.

Berkaitan dengan penggunaan dua jenis teknik alat ukur hasil belajar tersebut, umumnya guru-guru di sekolah lebih banyak menggunakan jenis teknik tes dibanding teknik non-tes. Sebagaimana yang diuraikan lebih lanjut oleh Nana Sudjana, bahwa guru dalam menggunakan bentuk non-tes untuk menilai hasil dan proses belajar masih sangat terbatas jika dibandingkan dengan bentuk tes dalam menilai hasil dan proses belajar peserta didik. Guru-guru di sekolah pada umumnya lebih banyak menggunakan tes daripada non-tes. Hal ini dapat terjadi oleh karena alat tes mudah dibuat, kemudian dapat digunakan lebih praktis, serta yang dinilai hanya terbatas pada aspek kognitif berdasarkan hasil belajar yang diperoleh peserta didik setelah menyelesaikan pengalaman belajarnya di kelas. ${ }^{5}$ Penyusunan teknik tes lebih mudah daripada teknik non-tes.

Kondisi senada diungkapkan oleh Sudaryono. Ia mengatakan bahwa penilaian nontes masih jarang digunakan dalam menilai hasil belajar mengajar, padahal data hasil

\footnotetext{
${ }^{1}$ Zainal Arifin, Evaluasi Pembelajaran: Prinsip, Teknik, dan Prosedur (Bandung: Remaja Rosdakarya, 2016), 42.

2 Asep Jihad dan Abdul Haris, Evaluasi Pembelajaran (Yogyakarta: Multi Pressindo, 2013), 14.

${ }^{3}$ Asep dan Abdul Haris, Evaluasi Pembelajaran, 15.

${ }^{4}$ Nana Sudjana, Penilaian Hasil Proses Belajar Mengajar (Bandung: Remaja Rosdakarya, 2013), 67.

${ }^{5}$ Sudjana, Penilaian Hasil Proses Belajar, 67.
} 
penilaian melalui alat-alat tersebut, tidak kalah maknanya dibandingkan dengan data penilaian melalui tes hasil belajar. ${ }^{6}$ Permasalahan ini dipertegas oleh Zainal Arifin. Ia menegaskan apabila evaluator hanya menggunakan teknik tes saja, maka data yang dikumpulkan menjadi kurang lengkap dan tidak bermakna, bahkan dapat merugikan pihak-pihak tertentu. Penggunaan teknik non-tes merupakan salah satu bentuk kritikan terhadap kelemahan teknik tes. ${ }^{7}$ Lebih lanjut Sukardi menegaskan bahwa bentuk atau alat ukur non-tes sangat berguna pada evaluasi hasil belajar yang berkaitan erat dengan kualitas pribadi dan keterampilan. Kualitas pribadi dan keterampilan ini secara tepat hanya dapat dievaluasi melalui penampilan sebagai efek penguasaan domain keterampilan dalam bentuk non-tes. ${ }^{8}$

Permasalahan lainnya diungkapkan oleh Hamzah B. Uno dan Satria Koni. ${ }^{9}$ Pengalaman mereka dalam memberikan pelatihan dan lokakarya bagi guru-guru, diperoleh informasi adanya keluhan dari guru karena mengalami kesulitan dalam melakukan penilaian pada peserta didik, khususnya aspek perilaku.Para guru mengalami kesulitan untuk memberikan kategori penilaian dan tidak mengerti tolak ukur dari aspek-aspek penilaian.Persoalan guru mengalami kesulitan dalam melakukan penilaian hasil belajar ranah afektif dan psikomotorik, menjadi persoalan yang mempertajam pembahasan dalam penelitian ini.

Gagasan para ahli dan persoalan pendidikan di atas menjadi gambaran bahwa permasalahan urgensi alat pengukuran hasil belajar jenis tes maupun non-tes dan kesulitan guru dalam menggunakannya, masih menjadi permasalahan yang sering terjadi dan menarik untuk dibahas.Terutama permasalahan yang berkaitan dengan penggunaan instrumen non-tes.Permasalahan inipun tentu tidak hanya dihadapi oleh guru-guru umum, melainkan juga dapat dihadapi oleh guru-guru Pendidikan Agama Kristen (PAK) di sekolah.Melalui tulisan ini, peneliti akan mencoba menganalisis seberapa jauh guru-guru PAK menggunakan instrumen non-tes dalam penilaian hasil belajar ranah afektif dan psikomotorik peserta didik di kelas. Peneliti juga ingin memastikan akan jawaban atas dugaan, apakah guru PAK mengabaikan instrumen nontes dalam penilaian ranah afektif dan psikomotorik. Untuk menjawab permasalahan tesis ini, peneliti akan melakukan penelitian melalui teknik survei pada guru-guru PAK di SMP Negeri 5 dan SMP Negeri 20 Kota Kupang. Data yang diperoleh akan dianalisis dan dikombinasikan dengan teori-teori pendukung yang berkaitan dengan telaah penilaian hasil belajar ranah afektif dan psikomotorik.

\section{Metode Penelitian}

Metode penelitian yang digunakan dalam penelitian ini adalah dengan menggunakan metode deskriptif kuantitatif dengan teknik survei.Instrumen penelitian menggunakan

\footnotetext{
${ }^{6}$ Sudaryono, Dasar-dasar Evaluasi Pembelajaran (Yogyakarta: Graha Ilmu, 2012), 133.

${ }^{7}$ Zainal Arifin, Evaluasi Pembelajaran, 152.

${ }^{8}$ H. M. Sukardi, Evaluasi Pendidikan: Prinsip dan Operasionalnya (Jakarta: Bumi Aksara, 2015), 193.

${ }^{9}$ Hamzah B. Uno dan Satria Koni, Assessment Pembelajaran (Jakarta: Bumi Aksara, 2018), 182.
} 
teknik pengumpulan data melalui angket. Angket terdiri atas 45 pertanyaan yang meliputi: 15 pertanyaan tentang ranah afektif, 15 pertanyaan tentang ranah psikomotorik, dan 15 pertanyaan tentang instrumen evaluasi non-tes. Peneliti menyebar angkat kepada 6 orang guru PAK, yaitu 4 orang guru PAK di SMP Negeri 5 dan 2 orang guru PAK di SMP Negeri 20 Kota Kupang. Penelitian ini, menggunakan teknik analisis penelitian dengan statistik deskriptif. Berikut hasil sebaran angket penelitian tersebut.

Tabel 1: Ranah Afektif

\begin{tabular}{ccccccccccccccccc}
\hline Res & 1 & 2 & 3 & 4 & 5 & 6 & 7 & 8 & 9 & 10 & 11 & 12 & 13 & 14 & 15 & Total \\
\hline 1 & 4 & 3 & 4 & 3 & 3 & 3 & 3 & 4 & 4 & 4 & 3 & 3 & 4 & 3 & 4 & 52 \\
2 & 4 & 3 & 3 & 3 & 3 & 3 & 4 & 4 & 4 & 4 & 2 & 4 & 4 & 3 & 4 & 52 \\
3 & 5 & 4 & 5 & 4 & 5 & 5 & 2 & 4 & 5 & 4 & 3 & 3 & 4 & 1 & 5 & 59 \\
4 & 4 & 4 & 4 & 4 & 4 & 4 & 1 & 4 & 4 & 5 & 1 & 5 & 5 & 1 & 5 & 55 \\
5 & 5 & 4 & 5 & 4 & 4 & 4 & 1 & 4 & 4 & 5 & 2 & 4 & 5 & 1 & 5 & 57 \\
6 & 4 & 3 & 5 & 3 & 3 & 4 & 1 & 3 & 4 & 5 & 2 & 4 & 5 & 1 & 4 & 51
\end{tabular}

Ket: Alternatif Jawaban Angket:

1 (Sangat Tidak Setuju), 2(Tidak Setuju), 3(Ragu-ragu), 4(Setuju), 5(Sangat Setuju)

Tabel 2: Ranah Psikomotorik

\begin{tabular}{ccccccccccccccccc}
\hline Res & 1 & 2 & 3 & 4 & 5 & 6 & 7 & 8 & 9 & 10 & 11 & 12 & 13 & 14 & 15 & Total \\
\hline 1 & 3 & 3 & 4 & 4 & 3 & 3 & 3 & 3 & 4 & 4 & 3 & 4 & 3 & 3 & 2 & 49 \\
2 & 4 & 3 & 4 & 4 & 3 & 3 & 3 & 4 & 4 & 4 & 3 & 4 & 3 & 3 & 3 & 52 \\
3 & 4 & 5 & 5 & 5 & 1 & 5 & 1 & 4 & 4 & 4 & 5 & 4 & 5 & 4 & 1 & 57 \\
4 & 5 & 4 & 4 & 4 & 1 & 5 & 2 & 5 & 4 & 1 & 3 & 4 & 4 & 4 & 1 & 51 \\
5 & 5 & 5 & 4 & 4 & 1 & 4 & 2 & 4 & 4 & 4 & 3 & 4 & 4 & 5 & 1 & 54 \\
6 & 5 & 4 & 4 & 4 & 2 & 4 & 3 & 4 & 4 & 4 & 3 & 4 & 4 & 5 & 1 & 55
\end{tabular}

Ket: Alternatif Jawaban Angket:

1 (Sangat Tidak Setuju), 2(Tidak Setuju), 3(Ragu-ragu), 4(Setuju), 5(Sangat Setuju)

Tabel 3: Hasil Belajar Pendidikan Agama Kristen

\begin{tabular}{ccccccccccccccccc}
\hline Res & 1 & 2 & 3 & 4 & 5 & 6 & 7 & 8 & 9 & 10 & 11 & 12 & 13 & 14 & 15 & Total \\
\hline 1 & 4 & 4 & 4 & 2 & 4 & 4 & 4 & 4 & 2 & 4 & 4 & 2 & 4 & 4 & 4 & 54 \\
2 & 4 & 3 & 3 & 2 & 3 & 3 & 3 & 3 & 2 & 3 & 4 & 3 & 3 & 4 & 4 & 47 \\
3 & 4 & 4 & 4 & 1 & 3 & 4 & 4 & 4 & 1 & 4 & 4 & 1 & 3 & 4 & 3 & 48 \\
4 & 5 & 5 & 5 & 2 & 4 & 5 & 5 & 2 & 2 & 4 & 4 & 1 & 5 & 5 & 5 & 59 \\
5 & 5 & 4 & 5 & 1 & 5 & 5 & 5 & 3 & 1 & 4 & 4 & 1 & 5 & 4 & 4 & 56 \\
6 & 5 & 5 & 5 & 1 & 5 & 4 & 5 & 3 & 1 & 4 & 4 & 1 & 5 & 5 & 4 & 57
\end{tabular}

Ket: Alternatif Jawaban Angket:

1 (Sangat Tidak Setuju), 2(Tidak Setuju), 3(Ragu-ragu), 4(Setuju), 5(Sangat Setuju) 


\section{Hasil dan Pembahasan}

Hasil dan pembahasan dalam penelitian ini terangkum dalam pembahasan teoritis dan analisa penelitian. Aspek teoritis mencakup pembahasan variabel dalam penelitian ini.Variabel penelitian initerdiri atas tiga bagian. Bagian tersebut mencakup variabel ranah afektif, ranah psikomotorik, dan instrumen evaluasi nontes. Pertama, aspek pembahasan teoritis. Aspek teoritis variabel penelitian ini adalah tiga variabel penelitian. Ketiga bagian ini memiliki peran yang saling berkaitan satu dengan yang lain. Peran tersebut dapat didalami dan dipahami dalam penjelasan teori sebagai berikut.

\section{Hakikat Ranah Afektif}

Ranah afektif merupakan salah satu ranah hasil belajar yang ada dalam diri peserta didik.Menurut teori Benjamin S. Bloom dalam Asep dan Abdul Haris, ada tiga ranah hasil belajar.Ketiga ranah hasil belajar itu adalah ranah kognitif, afektif dan psikomotorik. ${ }^{10}$ Dalam penelitian ini ketiga ranah tersebut tidak dibahas semua. Fokus pembahasan hanya dua ranah, yaitu ranah afektif dan ranah psikomotorik.

Ranah afektif memiliki pengertian sebagai berikut.Ranah afektif adalah ranah yang berkaitan dengan kemampuan sikap dan nilai. ${ }^{11}$ Sudjana lebih lanjut menguraikan bahwa tipe hasil belajar afektif tampak pada peserta didik dalam berbagai tingkah laku, seperti perhatiannya terhadap pelajaran, disiplin, motivasi belajar, menghargai guru dan teman sekelas, kebiasaan belajar, dan hubungan sosial.

Selain pembahasan pengertian hasil belajar ranah afektif di atas, terdapat juga ciri hasil belajar ranah afektif pada peserta didik. Berikut ini akan diuraikan ciri-ciri hasil belajar ranah afektif yang dapat dilihat pada peserta didik: ${ }^{12}$ pertama, sikap peserta didik pada waktu belajar di sekolah, terutama pada waktu guru mengajar. Sikap ini meliputi: kemampuan peserta didik untuk menerima pelajaran dari guru, perhatian peserta didik terhadap apa yang dijelaskan oleh guru, keinginan peserta didik untuk mendengarkan dan mencatat uraian dari guru, penghargaan peserta didik terhadap guru itu sendiri, serta hasrat peserta didik untuk bertanya kepada guru. Kedua, sikap peserta didik setelah pelajaran selesai. Sikap peserta didik ini meliputi indikator: kemauan peserta didik dalam mempelajari bahan pelajaran lebih lanjut, kemauan peserta didik untuk mengaplikasikan hasil pelajaran dalam praktik kehidupan seharihariberdasarkan tujuan dan isi yang tertuang dalam mata pelajaran, serta suka terhadap gurunya dan mata pelajarannya.

Hakikat dari hasil belajar ranah afektif juga membahas tentang jenjang atau tingkatan ranah afektif. Berikut ini ada lima tingkatan dalam ranah afektif, yaitu: ${ }^{13}$

\footnotetext{
${ }^{10}$ Asep dan Haris, Evaluasi Pembelajaran, 14.

11 Sudjana, Penilaian Hasil Proses Belajar, 29.

12 Sudjana, Penilaian Hasil Proses Belajar, 31.

${ }^{13}$ Asep dan Haris, Evaluasi Pembelajaran, 17-18.
} 
tingkatan pertama, menerima atau memperhatikan. Jenjang ini berkaitan dengan kemauan untuk menerima atau memerhatikan guru. Kata kunci yang dipakai meliputi: dengar, lihat, raba, cium, rasa, pandang, pilih, dan perhatikan. Tingkatan kedua, merespon. Dalam jenjang ini peserta didik dilibatkan secara puas dalam suatu subjek tertentu. Kata kunci yang dapat dipakai antara lain: persetujuan, minat, reaksi, membantu, partisipasi, dan melibatkan diri. Tingkatan ketiga ialah penghargaan. Pada jenjang ini aspek perilaku peserta didik ialah konsisten dan stabil. Kata kunci yang dapat dipakai ialah: mengakui dengan tulus, mengidentifikasi diri, memercayai, menyatukan diri, rela berkorban, dan tanggung jawab. Tingkatan keempat, mengorganisasikan. Dalam jenjang ini peserta didik membentuk suatu sistem nilai yang dapat menuntun perilaku. Kata kunci yang dapat dipakai, yaitu: menimbang-nimbang, menjalin, meyelaraskan, dan mengimbangkan membentuk filsafat hidup. Tingkatan kelima adalah mempribadi atau mewatak. Tingkatan akhir ini sudah memiliki internalisasi, serta nilai-nilai telah mendapatkan tempat pada diri individu. Kata-kata yang dapat dipakai: bersifat obyektif, bijaksana, adil, teguh dalam pendirian, percaya diri, dan berkepribadian.

Implikasi praktis yang dapat digunakan oleh guru PAK untuk menuangkan tingkatan ranah afektif tersebut adalah dengan menyesuaikannya dengan aspek-aspek penilaian yang tertuang dalam rapor peserta didik. Aspek-aspek tersebut adalah aspek kelakuan, kerajinan, kebersihan, kerapian, dan kedisiplinan. ${ }^{14}$ Aspek-aspek ini menjadi tolak ukur bagi guru PAK dalam melaksanakan penilaian ranah afektif peserta didik.

\section{Hakikat Ranah Psikomotorik}

Ranah psikomotorik adalah bentuk keterampilan (skill) dan kemampuan bertindak individu. ${ }^{15}$ Lebih lanjut Sudjana menguraikan tipe hasil belajar ranah psikomotorik berkaitan dengan keterampilan atau kemampuan untuk bertindak setelah peserta didik menerima pengalaman belajar tertentu. Hasil belajar ini merupakan tahap lanjutan dari hasil belajar afektif yang baru tampak dalam kecenderungan-kecenderungan peserta didik untuk berperilaku.

Ranah psikomotorik terdiri atas aktivitas motorik yang penting dalam pengembangan kemampuan peserta didik dalam memanipulasi benda-benda, dan secara umum mengembangkan keterampilan motorik peserta didik. ${ }^{16}$ Ranah psikomotorik juga berkaitan dengan gerakan sengaja yang dikendalikan oleh aktivitas otak. Dengan kata lain, psikomotorik umumnya berupa keterampilan yang memerlukan koordinasi otak dengan beberapa otot. Berkaitan dengan pengembangan ranah psikomotorik ini, peran guru sangat penting dan sangat diharapkan mampu melaksanakannya.

\footnotetext{
${ }^{14}$ Uno dan Koni, Assessment Pembelajaran, 183.

15 Sudjana, Penilaian Hasil Proses Belajar, 30.

${ }^{16}$ Sifra Sahiu dan Hengki Wijaya, "Hubungan Motivasi Belajar Ekstrinsik Terhadap Hasil Belajar Psikomotorik Pada Mata Pelajaran Agama Kristen Kelas V Di SD Zion Makassar." JURNAL JAFFRAY, Vol. 15, No. 2, Oktober 2017. https://ojs.sttjaffray.ac.id/index.php/JJV71/article/view/262
} 
Ranah psikomotorik memiliki limatahap atau jenjang perkembangan. Kelima jenjang tersebut adalah sebagai berikut: ${ }^{17}$ pertama, tahap menirukan. Pada jenjang ini jikadiaplikasikan kepada peserta didik suatu tindakan yang dapat diamati, maka peserta didik tersebutakan mulai membuat suatu tiruan terhadap tindakan itu sampai pada tingkat sistem otot-ototnya dan dituntun oleh dorongan kata hati untuk menirukan. Kata kunci yang digunakan meliputi: menirukan, pengulangan, berke-tetapan hati, mau, dan minat bergairah. Kedua, tahap manipulasi. Pada tahapan ini peserta didik dapat menunjukkan atau menampilkan suatu tindakan seperti yang dia-jarkan, sertatindakan yang juga tidak hanya seperti yang diamati. Peserta didik mulai dapat membedakan antara satu pola tindakan dengan yang lain, kemudian menjadi mampu memilih tindakan yang diperlukan dan mulai memiliki keterampilan dalam memanipulasi. Kata kunci yang dapat digunakan pada tahapan ini antara lain: ikuti petunjuk, tetapkan mencoba-coba, dan perbaikan tindakan.

Ketiga, tahap keseksamaan. Pada tahapan ini terdiri atas kemampuan peserta didik dalam menampilkan suatu tindakan yang telah sampai pada tingkat perbaikan yang lebih tinggi dalam mereproduksi suatu kegiatan tertentu. Kata kunci yang dapat digunakan pada tahapan ini, yaitu: lakukan kembali, kerjakan kembali, dan hasilkan. Keempat, tahap artikulasi.Tahapan ini memiliki unsur utama, yaitu peserta didik telah dapat mengkoordinasikan serentetan tindakan dengan menetapkan urutan secara tepat di antara tindakan yang berbeda-beda. Kata kunci yang dapat digunakan pada tahapan ini adalah: lakukan secara harmonis, serta lakukan secara unit. Kelima, tahap naturalisasi. Pada tahapan terakhir ini mengungkapkan bahwa apabila peserta didik telah dapat melakukan secara alami satu tindakan atau sejumlah tindakan yang urut, maka keterampilan penampilan tersebut telah sampai pada kemampuan yang paling tinggi dan tindakan tersebut ditampilkan dengan pengeluaran energi yang minimum.

Gambaran hasil belajar dalam ranah afektif dan ranah psikomotorik dapat dilihat pada tabel berikut ini:18

\section{Tabel:}

Hasil Belajar Ranah Afektif dan Ranah Psikomotorik

\begin{tabular}{|c|l|l|}
\hline No & \multicolumn{1}{|c|}{ Ranah Afektif } & \multicolumn{1}{c|}{ Ranah Psikomotorik } \\
\hline 1 & $\begin{array}{l}\text { Memiliki kemauan untuk } \\
\text { menerima pelajaran dari guru. }\end{array}$ & $\begin{array}{l}\text { Tindakan dengan segera memasuki kelas pada } \\
\text { waktu guru datang dan duduk secara baik } \\
\text { dengan mempersiapkan kebutuhan belajar. }\end{array}$ \\
\hline 2 & $\begin{array}{l}\text { Perhatian peserta didik terhadap } \\
\text { apa yang dijelaskan oleh guru. }\end{array}$ & $\begin{array}{l}\text { Memiliki catatan bahan pelajaran dengan baik } \\
\text { dan sistematis. }\end{array}$ \\
\hline 3 & $\begin{array}{l}\text { Penghargaan peserta didik } \\
\text { terhadap guru. }\end{array}$ & $\begin{array}{l}\text { Sikap sopan, ramah, dan hormat kepada guru } \\
\text { pada saat guru menjelaskan pelajaran. }\end{array}$ \\
\hline 4 & $\begin{array}{l}\text { Peserta didik menunjukkan } \\
\text { hasrat untuk bertanya kepada } \\
\text { guru. }\end{array}$ & $\begin{array}{l}\text { Mengangkat tangan dan bertanya kepada guru } \\
\text { mengenai bahan pelajaran yang belum jelas. }\end{array}$ \\
\hline
\end{tabular}

${ }^{17}$ Asep dan Haris, Evaluasi Pembelajaran, 18-19.
18 Sudjana, Penilaian Hasil Proses Belajar, 32. 


\begin{tabular}{|c|l|l|}
\hline 5 & $\begin{array}{l}\text { Peserta didik menunjukkan } \\
\text { kemauan untuk mempelajari } \\
\text { bahan pelajaran lebih lanjut. }\end{array}$ & $\begin{array}{l}\text { Memilik perpustakaan sebagai tempat untuk } \\
\text { belajar lebih lanjut dan meminta informasi } \\
\text { kepada guru tentang buku yang harus } \\
\text { dipelajari, atau segera membentuk kelompok } \\
\text { diskusi. }\end{array}$ \\
\hline 6 & $\begin{array}{l}\text { Kemauan peserta didik untuk } \\
\text { menerapkan hasil pelajaran. }\end{array}$ & $\begin{array}{l}\text { Melakukan latihan diri dalam memecahkan } \\
\text { masalah berdasarkan konsep bahan yang telah } \\
\text { diperoleh peserta didik atau menggunakannya } \\
\text { dalam praktik kehidupannya. }\end{array}$ \\
\hline 7 & $\begin{array}{l}\text { Peserta didik senang dengan guru } \\
\text { dan mata pelajaran yang } \\
\text { diberikan. }\end{array}$ & $\begin{array}{l}\text { Peserta didik akrab, mau bergaul, mau } \\
\text { berkomunikasi dengan guru, dan bertanya } \\
\text { atau meminta saran bagaimana mempelajari } \\
\text { mata pelajaran yang diajarkannya. }\end{array}$ \\
\hline
\end{tabular}

\section{Hakikat InstrumenEvaluasi Non-tes}

Hakikat instrumen evaluasi non-tes meliputi pengertian, kegunaan, dan jenis-jenis instrumen evaluasi non-tes. Pertama, pengertian instrumen evaluasi non-tes. Sebelum membahas pengertian instrumen evaluasi jenis non-tes, terlebih dahulu akan dibahas pengertian dari evaluasi itu sendiri. Secara teoritis Zainal Arifin menjelaskan arti dari evaluasi. Menurutnya evaluasi ialah suatu proses yang sistematis dan berkelanjutan untuk menetapkan suatu kualitas yang mencakup nilai dan arti dari sesuatu, berdasarkan pertimbangan dan kriteria tertentu dalam rangka menetapkan keputusan. ${ }^{19}$ Pengertian lain diungkapkan oleh Slameto dalam Sukardi. Ia mengungkapkan bahwa evaluasi merupakan kegiatan yang direncanakan secara cermat dan merupakan bagian yang terpenting dalam sistem pembelajaran dalam mengetahui apakah sistem itu baik atau tidak, serta untuk mengembangkan kemampuan belajar peserta didik, kemampuan mengajar guru, dan menyempurnakan program pengajaran. ${ }^{20}$

Pengertian berikutnya ialah tentang evaluasi non-tes. Evaluasi non-tes merupakan jenis penilaian dengan tidak menggunakan tes. Sigit Pramono menjelaskan pengertian dari evaluasi non-tes, yaitu penilaian yang dilakukan tanpa menguji peserta didik, melainkan dilakukan dengan menggunakan pengamatan secara sistematis, seperti: observasi, wawancara, menyebarkan angket, dan meneliti dokumen. ${ }^{21}$ Dari pengertian beberapa ahli di atas, maka dapat disimpulkan pengertian dari instrumen evaluasinontes.Instrumen evaluasi non-tes adalah jenis penilaian terhadap peserta didik dengan tidak menggunakan bentuk tes, melainkan bentuk pengamatan, wawancara, angket, dan meneliti dokumen-dokumen.

Kedua, kegunaan instrumen evaluasi non-tes.Instrumen evaluasi non-tes dalam suatu pembelajaran sangatlah penting, terutama dalam mengukur dan menilai ranah afektif dan psikomotorik. Sukardi menegaskan kegunaan dari non-tes.Ia menerangkan, alat ukur non-tes sangat berguna terutama pada evaluasi hasil pembelajaran yang erat kaitannya dengan kualitas pribadi dan keterampilan, yang mana hanya tepat dievaluasi

\footnotetext{
19 Arifin, Evaluasi Pembelajaran, 5.

20 Sukardi, Evaluasi Pendidikan, 2.

21 Sigit Pramono, Panduan Evaluasi Kegiatan Belajar Mengajar (Yogyakarta: DIVA Press, 2014), 194.
} 
melalui penampilan sebagai efek penguasaan aspek keterampilan. ${ }^{22}$ Hal yang sama ditekankan oleh Sudjana. Ia menjelaskan kelebihan non-tes dari tes. Kelebihan non-tes tersebut ialah sifatnya lebih komprehensif. Artinya, non-tes dapat digunakan untuk menilai berbagai aspek dari peserta didik sehingga tidak hanya untuk menilai aspek kognitif, tetapi juga aspek afektif dan psikomotoris. ${ }^{23}$ Dengan demikian, instrumen evaluasi non-tes memiliki peran yang sangat penting bagi seorang guru PAK dalam melaksanakan pengukuran dan penilaian ranah afektif dan psikomotorik.

Ketiga, jenis-jenis instrumen evaluasi non-tes. Jenis instrumen evaluasi non-tes terdapat berbagai macam. Dalam penelitian ini peneliti hanya akan membahas lima jenis instrumen evaluasi non-tes saja. Kelima jenis instrumen evaluasi non-tes itu adalah sebagai berikut:

\section{Observasi}

Pengertian dari observasi yaitu metode atau cara-cara dalam menganalisis dan mengadakan pencatatan secara sistematis mengenai tingkah laku dengan melihat atau mengamati individu atau kelompok secara langsung. ${ }^{24}$ Sementara itu menurut Arifin, observasi merupakan suatu proses pengamatan dan pencatatan secara sistematis, logis, objektif, serta rasional mengenai berbagai fenomena, baik dalamsituasi yang sebenarnya maupun dalam situasi buatan untuk mencapai tujuan tertentu. ${ }^{25}$ Adapun alat yang dapat digunakan dalam melakukan observasi disebut dengan pedoman observasi. Pada kegiatan evaluasi pembelajaran, observasi dapat digunakan untuk menilai proses dan hasil belajar peserta didik. Misalnya, tingkah laku peserta didik pada waktu belajar, peserta didik dalam berdiskusi, peserta didik dalam mengerjakan tugas, dan lain-lain.

Dalam rangka evaluasi hasil belajar, observasi digunakan sebagai teknik evaluasi untuk menilai kegiatan-kegiatan belajar yang bersifat keterampilan atau skill. ${ }^{26}$ Observasi perilaku peserta didik juga dapat dilakukan dengan menggunakan buku catatan khusus tentang kejadian-kejadian yang berkaitan dengan peserta didik selama di sekolah. Hasil observasi yang dilakukan oleh guru dapat dijadikan sebagai umpan balik dalam pembinaan. ${ }^{27}$

\section{Wawancara}

Wawancara memiliki pengertian, yaitu salah satu bentuk alat evaluasi jenis non-tes yang dilakukan melalui percakapan dan tanya jawab, baik langsung maupun tidak

22 Sukardi, Evaluasi Pendidikan, 193.

${ }^{23}$ Sudjana, Penilaian Hasil Proses Belajar, 67.

${ }^{24}$ Ngalim Purwanto, Prinsip-prinsip dan Teknik Evaluasi Pengajaran (Bandung: Remaja Rosdakarya, 2009), 149.

${ }^{25}$ Arifin, Evaluasi Pembelajaran, 153.

26Purwanto, Prinsip-prinsip dan Teknik, 150.

27Uno dan Koni, Assessment Pembelajaran, 30. 
langsung dengan peserta didik. ${ }^{28}$ Arti wawancara langsung ialahproses tanya jawab yang dilakukan secara langsung antara pewawancara atau guru dengan orang yang diwawancarai atau peserta didik tanpa melalui perantara. Sementara wawancara tidak langsung yaitu proses tanya jawab antara pewawancara atau guru yang menanyakan sesuatu kepada peserta didik melalui perantaraan orang lain atau media dengan tidak menemui langsung kepada sumbernya.

\section{Angket}

Angket atau kuesioner merupakan teknik pengumpulan data yang dilakukan dengan cara memberi seperangkat pertanyaan atau pernyataan tertulis kepada responden untuk dijawab. ${ }^{29}$ Dalam proses pembelajaran di kelas, responden yang dimaksud adalah peserta didik. Guru bertindak sebagai perumus dan pembuat angket.

\section{Daftar Cek (Check List)}

Pengertian dari daftar cek ialah suatu daftar yang berisi subjek dan aspek-aspek yang akan diamati oleh guru. ${ }^{30}$ Melalui daftar cek ini, dapat memungkinkan guru sebagai penilai untuk mencatat tiap-tiap kejadian yang penting dan yang menjadi fokus penilaian dari guru. Daftar cek mudah digunakan untuk menilai tes psikomotorik dimana guru/pengamat tinggal memberi tanda cek pada kompetensi yang muncul. ${ }^{31}$ Daftar cek memiliki banyak manfaatnya. Adapun manfaat dari daftar cek meliputi: membantu guru untuk mengingat-ingat apa yang harus diamati, serta dapat memberikan informasi kepada stakeholder. ${ }^{32}$

Penilaian unjuk kerja pada daftar cek berupa "ya" atau "tidak." Pada penilaian ini peserta didik mendapat nilai apabila criteria penguasaan kemampuan tertentu dapat diamati oleh penilai. Jika tidak dapat diamati, peserta didik tidak memperoleh nilai. ${ }^{33}$

\section{Studi Kasus}

Jenis non-tes berikutnya ialah studi kasus. Arti dari studi kasus adalah studi yang mendalam dan komprehensif tentang peserta didik, kelas atau sekolah yang memiliki kasus tertentu. ${ }^{34}$ Indikator studi kasus misalnya, peserta didik ada yang sangat cerdas, ada yang sangat lamban, sangat rajin, sangat nakal atau ada yang kesulitan dalam belajar. Dalam studi kasus, penekanan yang penting untuk diperhatikanialah diagnosis masalah-masalah peserta didik dan memberikan rekomendasi untuk mengatasinya. Pada pelaksanaan studi kasus, Arifin menjelaskan bahwa guru di sekolah harus terlebih dahulu mengumpulkan data dari berbagai sumber dengan menggunakan berbagai

${ }^{28}$ Arifin, Evaluasi Pembelajaran, 157.

${ }^{29}$ Sugiyono, Metode Penelitian Pendidikan: Pendekatan Kuantitatif, Kualitatif dan RED (Bandung: Alfabeta, 2016), 199.

30 Arifin, Evaluasi Pembelajaran, 164.

${ }^{31}$ Asep dan Haris, Evaluasi Pembelajaran, 83.

32 Arifin, Evaluasi Pembelajaran, 164.

33Uno dan Koni, Assessment Pembelajaran, 20.

${ }^{34}$ Arifin, Evaluasi Pembelajaran, 168. 
teknik dan alat pengumpulan data.Alat pengumpulan data yang dapat dugunakan oleh guru salah satunya adalah depth-interview, yaitu melakukan wawancara secara mendalam. ${ }^{35}$

Kedua, aspek analisis. Berdasarkan penjelasan teori di atas, peneliti mengujicobakan beberapa indikator dari teori variabel ranah afektif, psikomotorik, dan instrumen evaluasi nontes. Indikator-indikator tersebut peneliti jabarkan dalam bentuk angket dan disebar kepada 6 orang guru PAK di SMP Negeri 5 dan SMP Negeri 20 Kota Kupang. Adapun hasil penelitian menunjukkan bahwa:

\section{Variabel ranah afektif terhadap instrumen non-tes}

Hasil penelitian pengujian variabel ranah afektif terhadap instrumen non-tes menggambarkan adanya pengaruh positif antara hasil belajar ranah afektif dengan penggunaan instrumen non-tes. Ada pun hasil analisa statistik korelasi melalui SPSS antara $\left(\mathrm{X}_{1}\right)$ terhadap $(\mathrm{Y})$ dapat dilihat pada tabel berikut ini:

\begin{tabular}{|c|c|c|c|c|c|c|}
\hline \multicolumn{7}{|c|}{ ANOVA $^{\mathrm{a}}$} \\
\hline \multicolumn{2}{|r|}{ Model } & $\begin{array}{c}\text { Sum of } \\
\text { Squares }\end{array}$ & $\mathrm{df}$ & $\begin{array}{c}\text { Mean } \\
\text { Square } \\
\end{array}$ & $\mathrm{F}$ & Sig. \\
\hline \multirow[t]{3}{*}{1} & Regression & 3.292 & 1 & 3.292 & .111 & $.755^{b}$ \\
\hline & Residual & 118.208 & 4 & 29.552 & & \\
\hline & Total & 121.500 & 5 & & & \\
\hline \multicolumn{7}{|c|}{ a. Dependent Variable: Nontes } \\
\hline \multicolumn{7}{|c|}{ b. Predictors: (Constant), Afektif } \\
\hline
\end{tabular}

Hasil uji linearitas analisis regresi residu $\mathrm{X}_{1}$ terhadap $\mathrm{Y}$, dihasilkan $\mathrm{F}$ sebesar 0,111.F sebesar 0,111 adalah signifikan pada $\alpha=0,000(\alpha>0,05)$. Angka 0,111>0,05 atau angka 0,111 lebih besar dari pada 0,05 yang artinya hubungan antara $\mathrm{X}_{1}$ terhadap $\mathrm{Y}$ adalah linear. Berdasarkan $\mathrm{F}$ hitung pada tabel di atas, tingkat korelasi antara $\mathrm{X}_{1}$ terhadap $\mathrm{Y}$ adalah korelasi linear sangat lemah. Hal ini karena F sebesar 0,111>0,05. Apabila dikaitkan dengan tingkat korelasi angka 0,111 berada diantara 0-0,25 yang berarti tingkat korelasi sangat lemah. Artinya pengaruh penggunaan instrumen non-tes terhadap ranah afektif adalah sangat kecil.

\section{Variabel ranah psikomotorik terhadap instrumen non-tes}

Hasil penelitian pengujian variabel ranah psikomotorik terhadap instrumen non-tes mendeskripsikan adanya pengaruh positif antara hasil belajar ranah psikomotorik dengan penggunaan instrumen non-tes. Ada pun hasil analisa statistik korelasi antara $\left(\mathrm{X}_{2}\right)$ terhadap $(\mathrm{Y})$ dapat dilihat pada tabel di bawah ini:

\footnotetext{
35 Arifin, Evaluasi Pembelajaran, 168.
} 


\begin{tabular}{|c|c|c|c|c|c|c|}
\hline \multicolumn{7}{|c|}{ ANOVA $^{\mathrm{a}}$} \\
\hline \multicolumn{2}{|c|}{ Model } & $\begin{array}{l}\text { Sum of } \\
\text { Squares }\end{array}$ & $\mathrm{df}$ & $\begin{array}{l}\text { Mean } \\
\text { Square }\end{array}$ & $\mathrm{F}$ & Sig. \\
\hline \multirow[t]{3}{*}{1} & Regression & 8.595 & 1 & 8.595 & .305 & $.610^{\mathrm{b}}$ \\
\hline & Residual & 112.905 & 4 & 28.226 & & \\
\hline & Total & 121.500 & 5 & & & \\
\hline \multicolumn{7}{|c|}{ a. Dependent Variable: Nontes } \\
\hline \multicolumn{7}{|c|}{ b. Predictors: (Constant), Psikomotorik } \\
\hline
\end{tabular}

Hasil uji linearitas analisis regresi residu $\mathrm{X}_{2}$ terhadap $\mathrm{Y}$, dihasilkan $\mathrm{F}$ sebesar 0,305.F sebesar 0,305 adalah signifikan pada $\alpha=0,000(\alpha>0,05)$. Angka 0,305>0,05 atau 0,305 lebih besar dari pada 0,05 yang artinya hubungan antara $\mathrm{X}_{2}$ terhadap $\mathrm{Y}$ adalah linear. Berdasarkan $\mathrm{F}$ hitung di atas maka tingkat korelasi antara $\mathrm{X}_{2}$ terhadap $\mathrm{Y}$ adalah korelasi cukup kuat. Hal ini karena F sebesar 0,511>0,05. Apabila dikaitkan dengan tingkat korelasi angka 0,305 berada diantara 0,25-0,5. Angka tingkat korelasi ini memiliki pengertian cukup kuat. Artinya, pengaruh penggunaan instrumen non-tes pada hasil belajar ranah psikomotorik adalah cukup kuat.

\section{Variabel ranah afektif dan psikomotorik terhadap instrumen non-tes}

Hasil penelitian pengujian variabel ranah afektif dan psikomotorik terhadap instrumen non-tesmenggambarkan adanyapengaruh positif antara hasil belajar ranah afektif dan ranah psikomotorik secara bersama-sama dengan penggunaan instrumen non-tes. Ada pun hasil analisa statistik korelasi melalui SPSS antara $\left(\mathrm{X}_{1}\right)$ dan $\left(\mathrm{X}_{2}\right)$ terhadap $(\mathrm{Y})$ adalah sebagai berikut:

\begin{tabular}{|l|l|c|c|c|c|c|}
\hline \multicolumn{7}{|l|}{ ANOVA $^{\mathrm{a}}$} \\
\hline \multicolumn{2}{|l|}{} & $\begin{array}{c}\text { Sum of } \\
\text { Squares }\end{array}$ & $\mathrm{df}$ & $\begin{array}{c}\text { Mean } \\
\text { Square }\end{array}$ & $\mathrm{F}$ & Sig. \\
\hline \multirow{4}{*}{1} & Regression & 8.674 & 2 & 4.337 & .115 & $.895^{\mathrm{b}}$ \\
\cline { 2 - 7 } & Residual & 112.826 & 3 & 37.609 & & \\
\cline { 2 - 7 } & Total & 121.500 & 5 & & & \\
\hline \multicolumn{7}{|l}{ a. Dependent Variable: Nontes } \\
b. Predictors: (Constant), Psikomotorik, Afektif \\
\hline
\end{tabular}

Hasil uji linearitas analisis regresi residu $\mathrm{X}_{1}$ dan $\mathrm{X}_{2}$ terhadap $\mathrm{Y}$, dihasilkan $\mathrm{F}$ sebesar 0,115 .F sebesar 0,115 adalah signifikan pada $\alpha=0,000 \quad(\alpha>0,05)$. Angka 0,115>0,05 atau 0,115 lebih besar daripada 0,05 yang artinya hubungan antara $\mathrm{X}_{1}$ dan $\mathrm{X}_{2}$ terhadap $\mathrm{Y}$ adalah linear. Berdasarkan $\mathrm{F}$ hitung di atas, tingkat korelasi antara $\mathrm{X}_{1}$ dan $\mathrm{X}_{2}$ terhadap $Y$ adalah korelasi sangat lemah. Hal ini karena $F$ sebesar 0,115>0,05. Hasil analisa statistik menunjukkan hasil dan tingkat korelasi secara bersama-sama tersebut adalah 0,115.Angka ini berapa pada tingkat korelasi 0-0,25, yang artinya memiliki tingkat korelasi sangat lemah. Dengan kata lain, pengaruh yang ditimbulkan atas penggunaan 
instrumen non-tes pada hasil belajar ranah afektif dan ranah psikomotorik adalah sangat lemah.

Penjelasan yang dapat peneliti berikan atas hasil penelitian di atas adalah sebagai berikut: pengaruh instrumen evaluasi non-tespada hasil belajar ranah afektif dan ranah psikomotorik adalah sangat lemah. Artinya, guru-guru PAK di SMP Negeri 5 dan SMP Negeri 20 Kota Kupang belum efektif dalam mengunakan instrumen non-tes. Belum efektifnya penggunaan instrumen non-tes ini dapat dipengaruhi oleh beberapa faktor. Antara lain: guru-guru PAK mengalami kesulitan dalam menggunakan instrumen nontes secara efektif, serta kurang tersedianya waktu dalam mempersiapkan instrumen non-tes dalam pengukuran dan penilaian hasil belajar ranah afektif maupun psikomotorik. Kelemahan guru-guru PAK atas faktor-faktor ini perlu mendapat perhatian lebih lanjut.

Hasil belajar ranah afektif dan psikomotorik yang diberikan oleh guru-guru PAK bagi peserta didik tidak cukup atau sekedar ada nilai. Guru PAK perlu memerhatikan tolak ukur atau instrumen penilaian yang tepat dan dapat dipertanggungjawabkan secara akademik. Untuk itu, seorang guru PAK diharapkan tidak memandang rendah atau mengabaikan instrumen evaluasi non-tes dalam memberikan penilaian ranah afektif dan psikomotorik peserta didik.

Deskripsi hasil penelitian ini sejalan dengan hasil penelitian sejenis yang dilakukan oleh Anggarwati Riscaputantri dan Sri Wening. ${ }^{36}$ Penelitian mereka lakukan di Sekolah Dasar di Kabupaten Klaten. Hasil penelitiannya adalah sebagai berikut: Berdasarkan hasil penelitian yang dilakukan di Kabupaten Klaten menunjukkan bahwa dari 30 responden dari guru yang diberikan kuisioner menunjukkan bahwa 83,3\% guru tidak memiliki instrumen penilaian afektif. Hal ini tidak sejalan dengan pemahaman guru tentang pentingnya penilaian efektif yaitu sebesar 96\%. Sedangkan pada pelaksanaan penilaian ditemukan guru tidak melakukan penilaian afektif.

Kemudian mereka menindaklanjuti dengan wawancara. Hasil wawancara menunjukkan bahwa ketidaktersedianya instrumen afektif dikarenakan guru mengalami kesulitan dalam membuat instrumen penilaian afektif. Kesulitan tersebut disebabkan minimnya contoh penilaian afektif. Wawancara juga dilakukan terkait kendala waktu, sejauh ini kendala yang dialami guru selain kesulitan membuat intrumen yaitu waktu. Guru tidak memiliki cukup waktu untuk membuat instrumen penilaian afektif sehingga guru hanya observasi terhadap sikap yang ditunjukkan siswa pada saat di luar pembelajaran namun masih dalam lingkup sekolah.

\footnotetext{
${ }^{36}$ Anggarwati Riscaputantri dan Sri Wening, "Pengembangan Instrumen Penilaian Afektif Siswa Kelas IV Sekolah Dasar Di Kabupaten Klaten," https://journal.uny.ac.id/index.php/jpep/article/view/16885/11596 (diakses 09 Maret 2019).
} 
Uraian hasil penelitian yang diungkapkan oleh Anggarwati dan Sri di atas memberikan gambaran bahwa guru memiliki peran yang signifikan dalam penggunaan instrumen non-tes. Jika guru kesulitan dalam menggunakan instrumen non-tes, kemudian memiliki kendala dalam hal waktu, maka dapat dipastikan hasil belajar ranah afekfif maupun psikomotorik peserta didik akan mengalami kendala. Berkaitan dengan itu, prinsip berikutnya yang perlu diperhatikan oleh seorang guru PAK adalah menyadari betapa pentingnya aspek penilaian. Seperti ditegaskan oleh Mulyani Syamsuddin, aspek penilaian sangat penting dalam meningkatkan kualitas pelaksanaan program pembelajaran di sekolah. ${ }^{37}$ Untuk itu, seorang guru PAK perlu mengembangkan potensi dan kemampuannya dalam memahami dan menggunakan instrumen evaluasi non-tes dalam pengukuran dan penilaian hasil belajar ranah afektif dan psikomotorik peserta didik di sekolah.

\section{Kesimpulan}

Analisa dan pembahasan penelitian ini menyimpulkan bahwa pengaruh instrumen evaluasi non-tes pada hasil belajar ranah afektif dan ranah psikomotorik adalah sangat lemah. Artinya, guru-guru PAK di SMP Negeri 5 dan SMP Negeri 20 Kota Kupang belum efektif dalam mengunakan instrumen non-tes. Belum efektifnya penggunaan instrumen non-tes ini dapat dipengaruhi oleh beberapa faktor. Faktor tersebut adalah guru-guru PAK masih mengalami kesulitan dalam menggunakan instrumen non-tes secara efektif, serta kurang tersedianya waktu dalam mempersiapkan instrumen non-tes dalam penilaian hasil belajar ranah afektif maupun psikomotorik peserta didik. Dengan kata lain, guru-guru PAK dalam praktiknya mengabaikan dan masih lemah dalam hal menggunakan instrumen evaluasi non-tes dalam penilaian hasil belajar ranah afektif dan psikomotorik.

Hasil penelitian ini juga memberikan kesimpulan dan saran sebagai berikut: pertama, hasil belajar ranah afektif dan ranah psikomotorik melalui penggunaan instrumen non-tes masih lemah. Untuk itu disarankan agar guru-guru PAK memahami dengan baik serta dapat menggunakan instrumen non-tes lebih efektif lagi dalam penilaian pembelajaran di kelas. Kedua, pihak sekolah atau kepala sekolah sekiranya dapat memberikan kesempatan kepada guru-guru PAK untuk mengembangkan diri dengan mengikuti pelatihan-pelatihan yang berkaitan dengan pengembangan dan penggunaan instrumen evaluasi tes dan non-tes dalam pembelajaran di kelas. Sehingga guru-guru PAK memiliki kemampuan dalam menyusun dan menggunakan instrumen evaluasi non-tes secara efektif dalam penilaian ranah afektif dan psikomotorik.

${ }^{37}$ Mulyani Syamsuddin,"Pengembangan Instrumen Hasil Belajar Fisika Peserta Didik Kelas XI IPA SMA Negeri 1 Donri-Donri Kabupaten Soppeng." JURNAL PEP Educational Assessment, Vol. 1, No. 1, 2017. Diambil dari: http://ojs.unm.ac.id/UEA/article/view/3779 


\section{Referensi}

Arifin, Zainal. Evaluasi Pembelajaran: Prinsip, Teknik, dan Prosedur. Bandung: Remaja Rosdakarya, 2016.

Jihad, Asep dan Abdul Haris. Evaluasi Pembelajaran. Yogyakarta: Multi Pressindo, 2013.

Pramono, Sigit. Panduan Evaluasi Kegiatan Belajar Mengajar. Yogyakarta: DIVA Press, 2014.

Purwanto, Ngalim. Prinsip-prinsip dan Teknik Evaluasi Pengajaran. Bandung: Remaja Rosdakarya, 2009.

Riscaputantri, Anggarwati dan Sri Wening, "Pengembangan Instrumen Penilaian Afektif Siswa Kelas IV Sekolah Dasar Di Kabupaten Klaten," https://journal.uny.ac.id/index.php/jpep/article/view/16885/11596

Sahiu, Sifra dan Hengki Wijaya, "Hubungan Motivasi Belajar Ekstrinsik Terhadap Hasil Belajar Psikomotorik Pada Mata Pelajaran Agama Kristen Kelas V Di SD Zion Makassar." JURNAL JAFFRAY, Vol. 15, No. 2, Oktober 2017. Diambil dari:https://ojs.sttjaffray.ac.id/index.php/JJV71/article/view/262

Sudaryono. Dasar-dasar Evaluasi Pembelajaran. Yogyakarta: Graha Ilmu, 2012.

Sudjana, Nana. Penilaian Hasil Proses Belajar Mengajar. Bandung: Remaja Rosdakarya, 2013.

Sugiyono. Metode Penelitian Pendidikan: Pendekatan Kuantitatif, Kualitatif dan R\&D. Bandung: Alfabeta, 2016.

Sukardi, H. M. Evaluasi Pendidikan: Prinsip dan Operasionalnya. Jakarta: Bumi Aksara, 2015.

Syamsuddin, Mulyani. "Pengembangan Instrumen Hasil Belajar Fisika Peserta Didik

Kelas XI IPA SMA Negeri 1 Donri-Donri Kabupaten Soppeng." JURNAL PEP

Educational Assessment, Vol. 1, No. 1, 2017. Diambil dari:

http://ojs.unm.ac.id/UEA/article/view/3779

Uno, Hamzah B. dan Satria Koni. Assessment Pembelajaran. Jakarta: Bumi Aksara, 2018. 